\title{
THE INFLUENCE OF ETHANOL UPON MAINTAINED WATER DIURESIS IN MAN
}

\author{
BY JACK D. ROSENBAUM, SOLOMON PAPPER, HENRY W. COHEN, AND \\ REGINA MCLEAN
}

\author{
(From the Medical Service and Research Laboratory, Boston Veterans Administration Hospital, \\ and the Departments of Medicine, Tufts University School of Medicine and \\ Boston University School of Medicine, Boston, Mass.)
}

(Submitted for publication February 14, 1957; accepted April 4, 1957)

A number of reports indicate that in normal subjects the magnitude of the diuretic response to a large intake of water varies directly with the contemporaneous rate of solute excretion by the kidney (1-6). A previous communication from this laboratory (4) described a characteristic decline in the rate of urine flow from the initial peak value which follows administration of water. This decline takes place despite maintenance of the water load. It is more regularly observed in the seated than in the recumbent subject and is associated with a concomitant decline in the excretion rate of solute. Although it was considered unlikely that antidiuretic hormone $(\mathrm{ADH})$ plays a role in the decline in diuresis, this possibility has never been excluded. It was therefore decided to determine the effect of administration of ethyl alcohol, a known potent inhibitor of antidiuretic hormone release $(7-10)$, upon the decline in diuresis. The observations described in the present report support the view that the decline in rate of urine flow does not depend on antidiuretic hormone. However, in a minority of the studies some augmentation of urine flow followed alcohol administration, pointing to a pre-existent low level of antidiuretic activity.

\section{MATERIALS AND METHODS}

The subjects were nine adult males free from renal, endocrine and cardiovascular disease. Their ages ranged from 22 to 48 years. Three were healthy physicians; the other six volunteers were patients under treatment for mild skin disorders or other minor ailments. One of the physicians (J. R.) and one of the patients (B. C.) had previously served as subjects for numerous experiments requiring a maintained water load. None of the subjects regularly drank alcohol to excess, although there was considerable variation in the customary alcoholic intake of the various members of the group. One of the patients, F. F., drank very rarely, whereas another patient, B. C., occasionally drank heavily for several successive days. No dietary restrictions were imposed ex- cept in the case of B. C., whose dietary sodium intake was limited to $25 \mathrm{mEq}$. daily at the time of his second study.

Each study was begun after breakfast when the subject voided, was weighed, and received an oral water load of $20 \mathrm{ml}$. per kilo taken over a period of 20 to $40 \mathrm{~min}$ utes. Unless otherwise stated, the subjects remained seated in a straight chair throughout the study, except when they stood up to void and to be weighed, at intervals of 20 or $\mathbf{3 0}$ minutes. After each voiding, sufficient water was drunk to restore body weight to the value observed after the initial water loading. The water diuresis was continued in this fashion until the rate of diuresis had declined by at least $1.5 \mathrm{ml}$. per minute (range 1.6 to 7.6 ), at which time, approximately two to six hours after the mid-point of the period of initial water loading, alcohol was given. In seven experiments on six subjects the alcohol was taken as $120 \mathrm{ml}$. of 100 proof Bourbon whiskey (48 Gm. of ethyl alcohol); one subject took $120 \mathrm{ml}$. of 86 proof Scotch whiskey $(41.3 \mathrm{Gm}$. of alcohol) ; two subjects received intravenously $50 \mathrm{ml}$. (40 Gm.) of ethyl alcohol in a liter of a 5 per cent solution of invert sugar. The alcohol was taken over a period varying from 10 to 60 minutes, during which time, and for 50 to 200 minutes thereafter, urine collection continued and water losses were replaced as before. Samples of venous blood were obtained at the onset of water diuresis, just before alcohol was given and at the end of each experiment. Determinations were made of osmolality (expressed for convenience as milliosmols per liter), creatinine, sodium, potassium, chloride in serum and urine and of serum total protein, hemoglobin and hematocrit by methods previously employed in this laboratory $(11,12)$. Alcohol in blood and urine was determined by the procedure of Jetter and McLean (13) adapted for the Coleman Jr. spectrophotometer. In specimens of serum and urine containing alcohol, total solute concentration was taken as total osmolality minus alcohol concentration since the latter is freely diffusible and exists at equal concentration in blood and urine $(14,15) .1$

${ }^{1}$ It is recognized that solutes which undergo partial back-diffusion in the renal tubule (e.g., urea) obligate water; such obligation depends on the osmotic gradient exerted by the moiety restrained from free back-diffusion. However, no effective osmotic force can be exerted by alcohol since, as pointed out by Homer Smith (16): "At equilibrium, the $U / P$ ratio of alcohol per unit of 
TABLE I

Data pertaining to subjects whose rate of urine flow increased appreciably after ethanol administration

\begin{tabular}{|c|c|c|c|c|c|c|c|c|c|c|c|}
\hline \multirow[b]{2}{*}{ Subject } & \multirow[b]{2}{*}{$\begin{array}{c}\text { Elapeed } \\
\text { time }\end{array}$} & \multirow[b]{2}{*}{$\begin{array}{l}\text { Urine } \\
\text { flow }\end{array}$} & \multirow[b]{2}{*}{$\begin{array}{l}\text { Urine } \\
\text { conc.* }\end{array}$} & \multicolumn{4}{|c|}{ Renal excretion rate of } & \multicolumn{3}{|c|}{ Renal clearance of } & \multirow[b]{2}{*}{$\begin{array}{l}\text { Urine } \\
\text { alcohol } \\
\text { conc.* }\end{array}$} \\
\hline & & & & Sodium & $\begin{array}{l}\text { Potas- } \\
\text { sium }\end{array}$ & Chloride & $\begin{array}{l}\text { Total } \\
\text { solute* }\end{array}$ & Creat. & $\begin{array}{l}\text { Total } \\
\text { golute* } \\
\text { (Comm) }\end{array}$ & $\begin{array}{c}\text { Free } \\
\text { water } \\
\text { (C) }\end{array}$ & \\
\hline \multirow[t]{2}{*}{$\begin{array}{l}\text { F. F. } \\
24 \text { yrs. } 88.5 \mathrm{Kg} . \\
\text { Lymphedema } \\
\text { Seated }\end{array}$} & \multirow{2}{*}{$\begin{array}{c}\text { mins. } \\
110-150 \\
270-330 \\
330-370 \\
370-402 \\
(390-453) \dagger \\
402-470 \\
470-502 \\
502-530\end{array}$} & $\begin{array}{c}\text { ml./min. } \\
19.0 \\
14.2 \\
12.5 \\
11.4\end{array}$ & $\begin{array}{c}\text { milli- } \\
o s m . / L . \\
59 \\
57 \\
59 \\
61\end{array}$ & $\begin{array}{r}\mu E q . l \\
\min . \\
145 \\
119 \\
94 \\
74\end{array}$ & $\begin{array}{r}\mu E q . I \\
\text { min. } \\
156 \\
65 \\
51 \\
44\end{array}$ & $\begin{array}{c}\mu E q . / \\
\text { min. } \\
172 \\
105 \\
78 \\
72\end{array}$ & $\begin{array}{c}\text { MOsm./ } \\
\text { min. } \\
1,120 \\
812 \\
738 \\
691\end{array}$ & $\begin{array}{c}\text { ml./min. } \\
153 \\
142 \\
140 \\
144\end{array}$ & $\begin{array}{c}m b . / m i n . \\
4.0 \\
3.0 \\
2.7 \\
2.5\end{array}$ & $\begin{array}{c}\text { ml./min. } \\
15.0 \\
11.2 \\
9.8 \\
8.9\end{array}$ & $m M / L$ \\
\hline & & $\begin{array}{l}10.9 \\
14.2 \\
14.8\end{array}$ & $\begin{array}{l}75 \\
51 \\
48\end{array}$ & $\begin{array}{l}100 \\
101 \\
101\end{array}$ & $\begin{array}{l}21 \\
18 \\
25\end{array}$ & $\begin{array}{l}74 \\
80 \\
72\end{array}$ & $\begin{array}{l}812 \\
730 \\
716\end{array}$ & $\begin{array}{l}156 \\
146 \\
151\end{array}$ & $\begin{array}{l}3.0 \\
2.6 \\
2.6\end{array}$ & $\begin{array}{r}7.9 \\
11.6 \\
12.2\end{array}$ & $\begin{array}{r}10.0 \\
8.7 \\
6.7\end{array}$ \\
\hline \multirow[t]{2}{*}{$\begin{array}{l}\text { P. H. } \\
42 \text { yrs. } 90.1 \mathrm{Kg} . \\
\text { Low back strain } \\
\text { Seated }\end{array}$} & \multirow{2}{*}{$\begin{array}{c}25-85 \\
85-145 \\
145-205 \\
205-265 \\
265-327 \\
(270-325) \dagger \\
327-385 \\
385-455\end{array}$} & $\begin{array}{r}11.4 \\
9.2 \\
8.2 \\
6.1 \\
9.5\end{array}$ & $\begin{array}{l}85 \\
87 \\
87 \\
88 \\
87\end{array}$ & $\begin{array}{l}166 \\
113 \\
090 \\
060 \\
103\end{array}$ & $\begin{array}{r}166 \\
153 \\
123 \\
60 \\
31\end{array}$ & $\begin{array}{l}176 \\
131 \\
102 \\
059 \\
081\end{array}$ & $\begin{array}{l}970 \\
798 \\
711 \\
535 \\
815\end{array}$ & $\begin{array}{l}131 \\
121 \\
127 \\
127 \\
138\end{array}$ & $\begin{array}{l}3.6 \\
2.9 \\
2.6 \\
2.0 \\
3.0\end{array}$ & $\begin{array}{l}7.8 \\
6.3 \\
5.6 \\
4.1 \\
6.5\end{array}$ & 9.4 \\
\hline & & $\begin{array}{l}9.4 \\
9.3\end{array}$ & $\begin{array}{l}65 \\
62\end{array}$ & $\begin{array}{l}079 \\
071\end{array}$ & $\begin{array}{l}14 \\
18\end{array}$ & $\begin{array}{l}059 \\
058\end{array}$ & $\begin{array}{l}614 \\
564\end{array}$ & $\begin{array}{l}133 \\
127\end{array}$ & $\begin{array}{l}2.3 \\
2.1\end{array}$ & $\begin{array}{l}7.1 \\
7.2\end{array}$ & $\begin{array}{r}13.6 \\
7.8\end{array}$ \\
\hline \multirow[t]{2}{*}{$\begin{array}{l}\text { C. J. } \\
32 \text { yrs. } 79.7 \mathrm{Kg} . \\
\text { Anxiety state } \\
\text { Seated }\end{array}$} & \multirow{2}{*}{$\begin{array}{c}74-99 \\
99-124 \\
154-179 \\
179-211 \\
(190-210) \ddagger \\
211-241 \\
241-301 \\
301-331\end{array}$} & $\begin{array}{r}14.9 \\
13.7 \\
9.6 \\
9.8\end{array}$ & $\begin{array}{l}59 \\
61 \\
62 \\
64\end{array}$ & $\begin{array}{r}181 \\
148 \\
96 \\
122\end{array}$ & $\begin{array}{l}89 \\
88 \\
54 \\
39\end{array}$ & $\begin{array}{l}225 \\
212 \\
141 \\
146\end{array}$ & $\begin{array}{l}880 \\
834 \\
598 \\
632\end{array}$ & $\begin{array}{l}150 \\
155 \\
144 \\
152\end{array}$ & $\begin{array}{l}3.2 \\
3.1 \\
2.2 \\
2.3\end{array}$ & $\begin{array}{r}11.7 \\
10.6 \\
7.4 \\
7.5\end{array}$ & 3.8 \\
\hline & & $\begin{array}{l}11.7 \\
12.6 \\
10.7\end{array}$ & $\begin{array}{l}59 \\
48 \\
45\end{array}$ & $\begin{array}{r}147 \\
139 \\
86\end{array}$ & $\begin{array}{l}15 \\
13 \\
12\end{array}$ & $\begin{array}{r}144 \\
139 \\
87\end{array}$ & $\begin{array}{l}683 \\
610 \\
483\end{array}$ & $\begin{array}{l}144 \\
153 \\
149\end{array}$ & $\begin{array}{l}2.5 \\
2.2 \\
1.8\end{array}$ & $\begin{array}{r}9.2 \\
10.4 \\
8.9\end{array}$ & $\begin{array}{l}22.4 \\
19.8 \\
15.9\end{array}$ \\
\hline
\end{tabular}

* Total osmolal concentrations and total solute excretion rates are exclusive of alcohol excreted.

$\dagger$ Fifty $\mathrm{ml}$. of ethanol infused intravenously as a 5 per cent solution in 5 per cent invert sugar during this interval. $\ddagger$ One hundred and twenty $\mathrm{ml}$. Bourbon whiskey (100 proof) imbibed during this interval.

Free-water clearance $\left(\mathrm{C}_{\mathrm{B}_{2} \mathrm{O}}\right)$ was calculated as the difference between urine flow (V) and osmolar clearance (Cosm) as follows:

$$
\mathrm{C}_{\mathrm{H}_{2} \mathrm{O}}=\mathrm{V}-\mathrm{U}_{\mathrm{os} \mathrm{m}} \mathrm{V} / \mathrm{P}_{\mathrm{osm}} \text {, }
$$

in which Uosm and Posm are osmolality of urine and plasma, respectively.

\section{RESULTS}

In Table I are presented data pertaining to the three experiments in the three subjects whose urine flow, after declining from its initial peak value, showed a distinct rise associated with the administration of alcohol. Data for consecutive periods during the course of one experiment are given in Figure 1. Urine osmolality regularly declined following ethanol administration, the greatest fall for each subject being 13, 26, and 19 milliosmols per liter. Each subject of this group manifested a small rise in endogenous creatinine water is close to 1.0. Apparently the tubules, at least the distal tubules, and the collecting ducts are freely permeable to it." clearance (range 8 to $12 \mathrm{ml}$. per min.) during the period in which alcohol was given, but urine osmolality (corrected for alcohol content) did not fall during this period, and only in one of the three subjects ( $P . H$.$) did urine flow rise significantly$ prior to the fall in concentration. In subject $P . H$. the initial increase in flow was also associated with a 50 per cent rise in total solute excretion, but the increased rate of flow was maintained despite subsequent decline in total solute excretion and creatinine clearance when urine concentration fell. Thus, in all three subjects ethanol administration was followed by increments in the rate of urine flow which could be ascribed neither to increased excretion of solute nor to increased glomerular filtration rate, as reflected by endogenous creatinine clearance. On the other hand, these increments were associated with rises in free-water clearance and reduction in urine osmolality. The changes observed in these three subjects are those that would be anticipated if release of antidiuretic hormone had been incompletely suppressed prior 


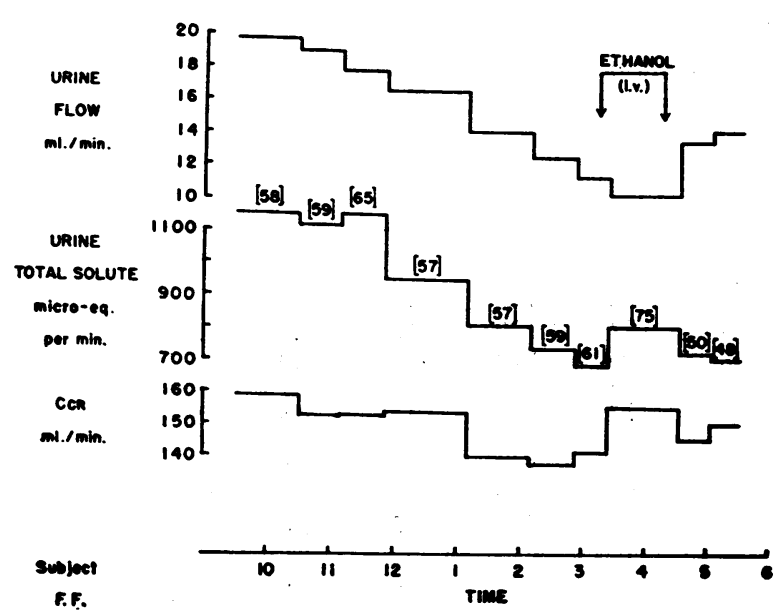

Fig. 1. Augmentation of Urine Flow Following ETHANOL INFUSION.

Bracketed numbers above line indicating total solute excretion are values for urine osmolality.

to ethanol administration, and more complete suppression was accomplished by the alcohol.

The decline in the rate of urine flow which preceded alcohol administration was not associated with a rise in urine osmolality, but was accompanied by a decline in solute excretion and in freewater clearance.

The data in Table II pertain to the seven experiments in six subjects whose urine flow, following its initial decline, did not increase after alcohol was given. Data for consecutive periods throughout a single experiment are presented in Figure 2. In four experiments the rate of diuresis continued to fall; in three it remained essentially constant after alcohol administration. Urine osmolality (corrected for alcohol content) remained virtually unchanged after alcohol was given in three experiments, rose by four milliosmols per liter in one and fell by six to nine milliosmols per liter in three. Changes in free-water clearance after alcohol were small, ranging from a fall of 1.6 to a rise of $0.6 \mathrm{ml}$. per minute. The absence of any clear-cut increase in urine flow or reduction in osmolality after alcohol was given points to preexistent suppression of antidiuretic hormone release that was virtually complete.

\section{DISCUSSION}

Hypotonicity of the body fluids must be established in order to attain a state of "physiologic diabetes insipidus" in the normal organism. However, the presence of hypotonicity alone does not ensure that suppression of antidiuretic hormone $(\mathrm{ADH})$ release will be achieved. A great many stimuli other than changes in effective osmolality influence the supra-optico-hypophyseal mechanism (11). Under the conditions of the experiments reported above, possible stimuli for $A D H$ release include emotional factors, the pain of venapuncture, and changes in the distribution of body fluids $(10,17-24)$. However, in none of the experiments were the usual features of ADH effect manifest. The abrupt fall in rate of urine flow with passage of darker and more concentrated urine, which may follow a painful stimulus or other disturbing experience in the course of a water diuresis, was not observed in these studies. The lowest rate of urine flow observed was $6.1 \mathrm{ml}$. per minute, and the highest osmolality 88 milliosmols per liter. The gradual, modest fall in rate of urine flow was not associated with the increase in urinary osmolality, which would be anticipated if $\mathrm{ADH}$ were operative. Finally, since alcohol is a potent inhibitor of $\mathrm{ADH}$ release, failure to observe augmentation in the rate of flow or a decrease in the osmolality of the urine when alcohol was given in seven of ten experiments is taken to indicate that suppression of ADH activity was virtually complete. Therefore, the decline in rate of urine flow in these subjects cannot reasonably be ascribed to $\mathrm{ADH}$ release. The failure to observe

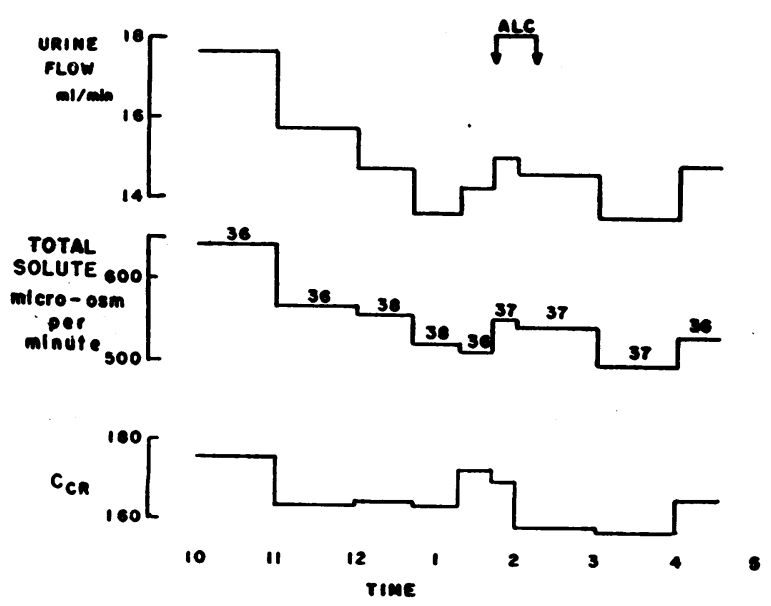

Fig. 2. Failure of Urine Flow or Concentration to Change After Alcohol Ingestion

Numbers above line indicating total solute excretion are values for urine osmolality. Subject B. F. 
TABLE II

Data pertaining to subjects whose rate of urine flow did not rise appreciably* after ethanol administration

\begin{tabular}{|c|c|c|c|c|c|c|c|c|c|c|c|}
\hline \multirow[b]{2}{*}{ Subject } & \multirow[b]{2}{*}{$\begin{array}{c}\text { Elapsed } \\
\text { time }\end{array}$} & \multirow[b]{2}{*}{$\begin{array}{l}\text { Urine } \\
\text { flow }\end{array}$} & \multirow[b]{2}{*}{$\begin{array}{c}\text { Urine } \\
\text { conc. }\end{array}$} & \multicolumn{4}{|c|}{ Renal excretion rate of } & \multicolumn{3}{|c|}{ Renal clearance of } & \multirow[b]{2}{*}{$\begin{array}{l}\text { Urine } \\
\text { alcohol } \\
\text { conc.t }\end{array}$} \\
\hline & & & & Sodium & $\begin{array}{l}\text { Potas- } \\
\text { sium }\end{array}$ & Chloride & $\begin{array}{l}\text { Total } \\
\text { solute† }\end{array}$ & Creat. & $\begin{array}{l}\text { Total } \\
\text { solutet } \\
\text { (Cosm) }\end{array}$ & $\begin{array}{c}\text { Free } \\
\text { water } \\
\text { (C) }\end{array}$ & \\
\hline \multirow{2}{*}{$\begin{array}{l}\text { J. R. } \\
42 \text { yrs. } 67.3 \mathrm{Kg} \text {. } \\
\text { Normal } \\
\text { Seated }\end{array}$} & \multirow{2}{*}{$\begin{array}{l}\text { mins. } \\
146-206 \\
236-296 \\
301-340 \ddagger \\
357-417\end{array}$} & $\begin{array}{c}\text { ml. } / m i n . \\
11.8 \\
7.5\end{array}$ & $\begin{array}{c}\text { milli- } \\
\text { osm./L. } \\
75 \\
79\end{array}$ & $\begin{array}{r}\mu E q .1 \\
\operatorname{mix.} \\
120 \\
46\end{array}$ & $\begin{array}{r}\mu B q . l \\
\min . \\
126 \\
36\end{array}$ & $\begin{array}{c}\mu E q . / \\
\min . \\
205 \\
58\end{array}$ & $\begin{array}{l}\text { Mosm.l } \\
\text { min. } \\
821 \\
595\end{array}$ & $\begin{array}{c}\text { ml. } / \text { min. } \\
106 \\
111\end{array}$ & $\begin{array}{c}\text { ml. } / \text { min. } \\
3.3 \\
2.2\end{array}$ & $\begin{array}{c}\text { ml. } / \text { min. } \\
8.5 \\
5.3\end{array}$ & $m M / L$ \\
\hline & & 7.9 & 70 & 75 & 18 & 64 & 561 & 108 & 2.0 & 5.9 & 20.5 \\
\hline \multirow{2}{*}{$\begin{array}{l}\text { B. F. } \\
31 \text { yrs. } 81.6 \mathrm{Kg} \text {. } \\
\text { Normal } \\
\text { Seated }\end{array}$} & \multirow{2}{*}{$\begin{array}{l}85-145 \\
245-305 \\
305-335 \ddagger \\
325-385\end{array}$} & $\begin{array}{l}17.6 \\
13.9\end{array}$ & $\begin{array}{l}36 \\
37\end{array}$ & $\begin{array}{l}70 \\
54\end{array}$ & $\begin{array}{l}72 \\
56\end{array}$ & $\begin{array}{r}128 \\
91\end{array}$ & $\begin{array}{l}639 \\
517\end{array}$ & $\begin{array}{l}176 \\
167\end{array}$ & $\begin{array}{l}2.3 \\
1.9\end{array}$ & $\begin{array}{l}15.3 \\
12.0\end{array}$ & \\
\hline & & 14.6 & 37 & 74 & 42 & 92 & 542 & 158 & 2.0 & 12.6 & 20.8 \\
\hline \multirow{2}{*}{$\begin{array}{l}\text { O. D. } \\
22 \text { yrs. } 88.2 \mathrm{Kg} \text {. } \\
\text { Chr. bronchitis } \\
\text { Seated }\end{array}$} & \multirow{2}{*}{$\begin{array}{l}132-182 \\
292-333 \\
340-351 \ddagger \\
413-453\end{array}$} & $\begin{array}{l}17.7 \\
16.1\end{array}$ & $\begin{array}{l}50 \\
50\end{array}$ & $\begin{array}{l}62 \\
58\end{array}$ & $\begin{array}{r}116 \\
95\end{array}$ & $\begin{array}{r}114 \\
70\end{array}$ & $\begin{array}{l}894 \\
802\end{array}$ & $\begin{array}{l}158 \\
155\end{array}$ & $\begin{array}{l}3.2 \\
2.9\end{array}$ & $\begin{array}{l}14.5 \\
13.2\end{array}$ & \\
\hline & & 14.9 & 41 & 29 & 33 & 18 & 612 & 162 & 2.2 & 12.7 & 9.7 \\
\hline \multirow{2}{*}{$\begin{array}{l}\text { T. T. } \\
32 \text { yrs. } 73.0 \mathrm{Kg} . \\
\text { Normal } \\
\text { Seated }\end{array}$} & \multirow{2}{*}{$\begin{array}{l}48-115 \\
115-160 \\
302-3308 \\
358-420\end{array}$} & $\begin{array}{l}12.9 \\
11.0\end{array}$ & $\begin{array}{l}55 \\
56\end{array}$ & $\begin{array}{l}80 \\
63\end{array}$ & $\begin{array}{l}93 \\
67\end{array}$ & $\begin{array}{l}98 \\
73\end{array}$ & $\begin{array}{l}702 \\
618\end{array}$ & $\begin{array}{l}156 \\
156\end{array}$ & $\begin{array}{l}2.5 \\
2.2\end{array}$ & $\begin{array}{r}10.4 \\
8.8\end{array}$ & \\
\hline & & 11.6 & 50 & 78 & 29 & 53 & 571 & 171 & 2.1 & 9.5 & 16.0 \\
\hline \multirow{2}{*}{$\begin{array}{l}\text { W. C. } \\
25 \text { yrs. } 67.8 \mathrm{Kg} \text {. } \\
\text { Conv. polio. } \\
\text { Recumbent }\end{array}$} & \multirow{2}{*}{$\begin{array}{l}80-110 \\
110-140 \ddagger \\
145-157 \\
230-260\end{array}$} & $\begin{array}{l}19.7 \\
17.0\end{array}$ & $\begin{array}{l}38 \\
40\end{array}$ & $\begin{array}{l}49 \\
28\end{array}$ & $\begin{array}{l}90 \\
90\end{array}$ & $\begin{array}{l}82 \\
50\end{array}$ & $\begin{array}{l}750 \\
680\end{array}$ & $\begin{array}{l}143 \\
167\end{array}$ & $\begin{array}{l}2.7 \\
2.5\end{array}$ & $\begin{array}{l}17.0 \\
14.5\end{array}$ & \\
\hline & & 15.1 & 39 & 59 & 34 & 40 & 598 & 145 & 2.2 & 12.9 & 20.7 \\
\hline \multirow{2}{*}{$\begin{array}{l}\text { B. C. } \\
48 \text { yrs. } 67.4 \mathrm{Kg} . \\
\text { Eczematoid derm. } \\
\text { Recumbent }\end{array}$} & \multirow{2}{*}{$\begin{array}{l}140-170 \\
230-260 \\
302-310 \ddagger \\
450-510\end{array}$} & $\begin{array}{r}10.8 \\
9.0\end{array}$ & $\begin{array}{l}74 \\
79\end{array}$ & $\begin{array}{r}111 \\
82\end{array}$ & $\begin{array}{r}102 \\
84\end{array}$ & $\begin{array}{r}119 \\
94\end{array}$ & $\begin{array}{l}802 \\
711\end{array}$ & $\begin{array}{l}144 \\
146\end{array}$ & $\begin{array}{l}3.0 \\
2.7\end{array}$ & $\begin{array}{l}7.8 \\
6.3\end{array}$ & \\
\hline & & 7.9 & 80 & 79 & 26 & 92 & 637 & 146 & 2.4 & 5.5 & 21.7 \\
\hline \multirow{2}{*}{$\begin{array}{l}\text { B. C. } \\
48 \text { yrs. } 64.8 \mathrm{Kg} \text {. } \\
\text { Eczematoid derm. } \\
\text { Recumbent }\end{array}$} & \multirow{2}{*}{$\begin{array}{l}50-80 \\
140-170 \\
141-157 \ddagger \\
260-290\end{array}$} & $\begin{array}{r}10.3 \\
8.5\end{array}$ & $\begin{array}{l}65 \\
77\end{array}$ & $\begin{array}{l}47 \\
18\end{array}$ & $\begin{array}{l}63 \\
37\end{array}$ & $\begin{array}{l}42 \\
24\end{array}$ & $\begin{array}{l}670 \\
654\end{array}$ & $\begin{array}{l}134 \\
133\end{array}$ & $\begin{array}{l}2.5 \\
2.4\end{array}$ & $\begin{array}{l}7.8 \\
6.1\end{array}$ & \\
\hline & & 6.5 & 81 & 32 & 24 & 23 & 520 & 112 & 1.9 & 4.6 & 22.4 \\
\hline
\end{tabular}

* Greatest rise in this group was $0.7 \mathrm{ml}$. per min. in B. F., whose urine osmolality did not change while $C_{B g}$ rose slightly.

t Total osmolal concentrations and total solute excretion rates are exclusive of alcohol excreted.

$\ddagger$ One hundred and twenty $\mathrm{ml}$. Bourbon whiskey (100 proof) imbibed during this interval.

One hundred and twenty $\mathrm{ml}$. Scotch whiskey (86 proof) imbibed during this interval.

a diuretic response to alcohol administration either during the initial peak of a water diuresis (10) or when, despite maintenance of the water load, urine flow declines in the seated subject indicates that a state of essentially complete physiologic diabetes insipidus may persist throughout a period of several hours at least. These observations support the view that, in the absence of important changes in glomerular filtration rate, changes in solute excretion are responsible for the variations in the diuretic response to ingested water (4).

Nevertheless the data do indicate that in three of the subjects some $\mathrm{ADH}$ effect was operative, albeit of insufficient magnitude to produce a low rate of urine flow or a hypertonic urine. This in- ference is based upon the observation that in these three subjects an increase in urine flow and a fall in urine osmolality with virtually no change in creatinine clearance or solute excretion followed the administration of alcohol. It may be noted that two of these subjects seemed quite tense during the experimental period prior to ethanol administration. However, it is doubtful if $\mathrm{ADH}$ was responsible for the decline in diuresis in these three subjects since initial rates of urine flow were not restored following alcohol administration and since urine osmolality did not rise as rate of flow fell. Indeed a relatively constant osmolality was observed during the periods prior to ethanol administration with a distinct fall in concentration 
after alcohol was given. It seems probable, therefore, that in these three individuals a small, relatively constant level of $\mathrm{ADH}$ activity was present until alcohol inhibited further release of the hormone. Obviously other patterns of response to the experimental situation might occur, including initial complete suppression of $\mathrm{ADH}$ release followed by slight $\mathrm{ADH}$ activity coincident with the subsequent decline of diuresis.

Clinical studies suggest that in certain patients with diabetes insipidus the ability to elaborate some antidiuretic hormone is not entirely abolished, since the urine may become less copious and more concentrated after administration of an extraordinarily potent antidiuretic stimulus in the form of a large dose of nicotine $(25,26)$. Apart from such observations in which an attendant fall in filtration rate may complicate interpretation $(27,28)$, the possibility has not been explored that small amounts of hormone, insufficient to produce hypertonicity of the urine and oliguria, may be released in some patients with clinical diabetes insipidus in response to more physiologic stimuli. The observations in the three subjects of the present study who appeared to have incomplete suppression of $\mathrm{ADH}$ release after water loading suggest that in patients with clinical diabetes insipidus the response to ethanol administration, under conditions of moderate dehydration with hypertonicity of the body fluids, might be useful in establishing the presence or absence of very small amounts of ADH.

\section{SUMMARY}

1. The influence of alcohol administration upon the decline in rate of urine flow, which characteristically occurs when a large water load is maintained in the seated normal subject, has been studied in ten experiments on nine adult males.

2. In seven experiments on six subjects ethanol administration during the decline in diuresis failed to raise the rate of flow or to lower the osmolality of the urine (corrected for alcohol content).

3. In three subjects a distinct rise in urine flow and fall in urine osmolality followed the administration of ethanol.

4. Since alcohol is known to be a potent inhibitor of antidiuretic hormone, these inferences are drawn: 1) that virtually complete physiologic diabetes insipidus may be established and maintained by maintaining a large water load, and 2) that the decline in rate of water diuresis does not require $\mathrm{ADH}$ release.

5. Under similar experimental conditions of maintained water loading, certain subjects continued to release very small amounts of $\mathrm{ADH}$, the presence of which may be recognized only if urine flow increases and concentration falls after ethanol is administered.

\section{ACKNOWLEDGMENT}

Financial assistance for procurement of reprints was provided by the Gray Pharmaceutical Company, Newton, Mass.

\section{REFERENCES}

1. Brodsky, W. A., and Rapoport, S., The mechanism of polyuria of diabetes insipidus in man. The effect of osmotic loading. J. Clin. Invest., 1951, 30, 282.

2. Wesson, L. G., Jr., and Anslow, W. P., Jr., Effect of osmotic and mercurial diuresis on simultaneous water diuresis. Am. J. Physiol., 1952, 170, 255.

3. Ladd, M., Renal excretion of sodium and water in man as affected by prehydration, saline infusion, pitressin and thiomerin. J. Applied Physiol., 1952, 4, 602 .

4. Rosenbaum, J. D., Nelson, W. P., III, Strauss, M. B., Davis, R. K., and Rossmeisl, E. C., Variation in the diuretic response to ingested water related to the renal excretion of solutes. J. Clin. Invest., 1953, 32, 394.

5. Welt, L. G., Young, D. T., Thorup, O. A., Jr., and Burnett, C. H., A study of renal tubular phenomena under the influence of a carbonic anhydrase inhibitor. J. Clin. Invest., 1954, 33, 972.

6. Kleeman, C. R., Epstein, F. H., and White, C., The effect of variations in solute excretion and glomerular flltration on water diuresis. J. Clin. Invest., 1956, 35, 749.

7. Eggleton, M. G., The diuretic action of alcohol in man. J. Physiol., 1942, 101, 172.

8. Strauss, M. B., Rosenbaum, J. D., and Nelson, W. P., III, The effect of alcohol on the renal excretion of water and electrolyte. J. Clin. Invest., 1950, 29, 1053.

9. van Dyke, H. B., and Ames, R. G., Alcohol diuresis. Acta endocrinol., 1951, 7, 110.

10. Kleeman, C. R., Rubini, M. E., Lamdin, E., and Epstein, F. H., Studies on alcohol diuresis. II. The evaluation of ethyl alcohol as an inhibitor of the neurohypophysis. J. Clin. Invest., 1955, 34, 448.

11. Strauss, M. B., Davis, R. K., Rosenbaum, J. D., and Rossmeisl, E. C., "Water diuresis" produced during recumbency by the intravenous infusion of isotonic saline solution. J. Clin. Invest., 1951, 30, 862. 
12. Birchard, W. H.; Prout, T. E., Williams, T. F., and Rosenbaum, J. D., Diuretic responses to oral and intravenous water loads in patients with hepatic cirrhosis. J. Lab. \& Clin. Med., 1956, 48, 26.

13. Jetter, W. W., and McLean, R., Poisoning by the synergistic effect of phenobarbital and ethyl alcohol. An experimental study. Arch. Path., 1943, $36,112$.

14. Jetter, W. W., A critical survey of various chemical methods for determining the alcohol content of body fluids and tissues with their physiological and medicolegal significance. Quart. J. Stud. on Alcohol., 1941, 2, 512.

15. Rubini, M. E., Kleeman, C. R., and Lamdin, E., Studies on alcohol diuresis. I. The effect of ethyl alcohol ingestion on water, electrolyte and acidbase metabolism. J. Clin. Invest., 1955, 34, 439.

16. Smith, H. W., The Kidney. New York, Oxford University Press, 1951, p. 281.

17. Verney, E. B., The antidiuretic hormone and the fact'rs which determine its release. Proc. Roy. Src., L'sndon, s.B., 1947, 135, 25.

18. Kelsall, A. R., The inhibition of water diuresis in man by ischaemic muscle pain. J. Physiol., 1949, 1 CS, 150.

19. Ke,lsall, A. R., The urinary excretion of creatinine during inhibition of water diuresis in man by ischaemic muscle pain. J. Physiol., 1951, 112, 54.
20. Brun, C., Knudsen, E. O. E., and Raaschou, F., Postsyncopal oliguria. Kidney function and circulatory collapse. Acta med. Scandinav., 1945, 122 , 381.

21. Brun, C., Knudsen, E. O. E., and Raaschou, F., On the cause of post-syncopal oliguria. Acta med. Scandinav., 1945, 122, 486.

22. Brun, C., Knudsen, E. O. E., and Raaschou, F., Kidney function and circulatory collapse. Post-syncopal oliguria. J. Clin. Invest., 1946, 25, 568.

23. Pearce, M. L., and Newman, E. J., Some postural adjustments of salt and water excretion. J. Clin. Invest., 1954, 33, 1089.

24. Newman, E. V., Metabolic adjustments to normal and disturbed circulation in man. New England J. Med., 1954, 250, 347.

25. Lewis, A. A. G., and Chalmers, T. M., A nicotine test for the investigation of diabetes insipidus. Clin. Sc., 1951, 10, 137.

26. Cates, J. E., and Garrod, O., The effect of nicotine on urinary flow in diabetes insipidus. Clin. Sc., 1951, $10,145$.

27. del Greco, F., and de Wardener, H. E., The effect on urine osmolarity of a transient reduction in glomerular filtration rate and solute output during a 'water' diuresis. J. Physiol., 1956, 131, 307.

28. Berliner, R. W., and Davidson, D. G., Production of hypertonic urine in the absence of pituitary antidiuretic hormone. J. Clin. Invest., 1956, 35, 690.

\section{SPECIAL NOTICE TO SUBSCRIBERS}

Post Offices will no longer forward the Journal when you move.

Please notify The Journal of Clinical Investigation, Business Office, 333 Cedar Street, New Haven 11, Conn. at once when you have a change of address, and do not omit the zone number if there is one. 